\title{
Physiology and Prediction of Fruit Tolerance to Low-oxygen Atmospheres
}

\author{
Dangyang Ke, Leonor Rodriguez-Sinobas, and Adel A. Kader \\ Department of Pomology, University of California, Davis, CA 95616
}

Additional index words. apple, Malus domestica, Asian pear, Pyrus serotina, plum, Prunus domestica, soluble solids content, ethanol, off-flavor

\begin{abstract}
Fruits of 'Granny Smith' and 'Yellow Newtown' apples (Malus domestica Borkh), '20th Century' pear (Pyrus serotina L.), and 'Angeleno' plum (Prunus domestica L.) were kept in air and in $0.25 \%$ or $0.02 \% \mathbf{O}_{2}$ at 0,5 , or $10 \mathrm{C}$ for $3,7,14,25$, or 35 days to study the effects of low- ${ }_{2}$ atmospheres on their postharvest physiology and quality attributes. Soluble solids content (SSC), pH, and external appearance were not significantly influenced, but resistance to $\mathrm{CO}_{2}$ diffusion was increased by the low- $\mathrm{O}_{2}$ treatments. Exposures to the low- $\mathrm{O}_{2}$ atmospheres inhibited ripening, including reduction in ethylene production rate, retardation of skin color changes and flesh softening, and maintenance of titratable acidity. The most important detrimental effect of the low- $\mathrm{O}_{2}$ treatments was development of an alcoholic off-flavor that had a logarithmic relation with ethanol content of the fruits. The ethanol content causing slight off-flavor $\left(E_{0}\right)$ increased with SSC of the commodity at the ripe stage, and it could be estimated using the following formula: $\left(\log \mathrm{E}_{\mathrm{o}}\right) / \mathrm{SSC}=\mathbf{0 . 2 2 8}$. Using $\mathrm{SSC}$ of ripe fruits and average ethanol accumulation rate per day $\left(\mathrm{V}_{\mathrm{E}}\right)$ from each low- $\mathrm{O}_{2}$ treatment, the tolerance limit $\left(\mathrm{T}_{1}\right)$ of fruits to low- $\mathrm{O}_{2}$ atmospheres could be predicted as follows: $\mathbf{T}_{1}=\mathbf{E}_{\mathrm{o}} / \mathbf{V}_{\mathrm{E}}=\left(10^{0.228 \mathrm{ssc}}\right) / \mathbf{V}_{\mathrm{E}}$.
\end{abstract}

Extensive studies have been done to investigate the effects of controlled atmospheres (CA) on postharvest physiology and quality attributes of apples (Bramlage, 1977; Chen et al., 1985, 1989; Couey and Olsen, 1977; Dewey and Bourne, 1982; Johnson and Ertan, 1983; Lau, 1983; Lidster et al., 1983; Little et al., 1982; Liu and Ci, 1986; Porrits and Meheriuk, 1977). Beneficial effects of low- $\mathrm{O}_{2}$ and/or high- $\mathrm{CO}_{2}$ atmospheres on extending the storage life of apples include reduction in rates of respiration and ethylene production, color changes, and softening; maintenance of vitamins, sugars, acids, and flavor; and inhibition of some physiological disorders and decay. However, prolonged storage of apples in stress levels of low- $\mathrm{O}_{2}$ and/or high- $\mathrm{CO}_{2}$ atmospheres may cause detrimental effects, such as accumulation of ethanol and acetaldehyde, development of offflavor, failure to ripen after removal to air, and development of low- $\mathrm{O}_{2}$ and/or high- $\mathrm{CO}_{2}$ injury (Fidler and North, 1971; Little and Peggie, 1987; Nichols. and Patterson, 1987; Patterson and Nichols, 1988).

Very little work has been done to study the effects of low $\mathrm{O}_{2}$ and/or high $\mathrm{CO}_{2}$ on Asian pears. Zagory et al. (1989) found no obvious benefits for CA in long-term storage of 'Early Gold' and 'Shinko' pears. Asian pears are also quite susceptible to low- $\mathrm{O}_{2}$ and high- $\mathrm{CO}_{2}$ injuries (such as discolored surface depressions or flesh browning) that were observed after 4 to 6 months of storage in $1 \%$ to $3 \% \mathrm{O}_{2}$ or in air enriched with $5 \%$ $\mathrm{CO}_{2}$ (Richardson, 1985).

Low- $\mathrm{O}_{2}$ and/or high- $\mathrm{CO}_{2}$ atmospheres reduced respiration rate, softening, decay, and loss of soluble solids and extended the storage life of plums (Claypool and Allen, 1951; Couey, 1960, 1965; Maxie et al., 1958; Sive and Resnizky, 1979). Storage of peaches and nectarines in $1 \% \mathrm{O}_{2}+5 \% \mathrm{CO}_{2}$ with intermittent warming reduced internal breakdown, extended storage life, and maintained levels of sugars, acids, and unsaturated fatty acids (Wang and Anderson, 1982). Treatments with low $\mathrm{O}_{2}$ and/or high $\mathrm{CO}_{2}$ were also reported to retard softening and color changes

Received for publication on 9 Feb. 1990. Research supported, in part, by gran no. 88-0618 from the California Dept. of Food and Agriculture and American President Lines. We thank Heidi Wutscher and Chao Ding for their laboratory assistance during this study. The cost of publishing this paper was defrayed in part by the payment of page charges. Under postal regulations, this paper therefore must be hereby marked advertisement solely to indicate this fact. and reduce respiration and ethylene production rates of peaches and nectarines (Anderson, 1982; Kerbel et al., 1989; Smilanick and Fouse, 1989; Wang and Anderson, 1982). Storage of cherries in CA conditions retarded color darkening and reduction in SSC and titratable acidity (Chen et al., 1981; Patterson, 1982). CA treatments were also reported to be beneficial to the storage of apricots (Wankier et al., 1970). However, when stone fruits were stored in stress-inducing $\mathrm{O}_{2}$ and/or $\mathrm{CO}_{2}$ concentrations for a period longer than tolerable, detrimental effects, such as abnormal ripening, flesh browning, and large increases in ethanol and acetaldehyde contents, occurred (Kader, 1986; Smilanick and Fouse, 1989).

To meet quarantine requirements for fresh fruits and vegetables, there has been an increased interest in recent years in studying the potential of short-term exposure to $\mathrm{O}_{2}$ levels below $1 \%$ and/or $\mathrm{CO}_{2}$ levels above $50 \%$ for postharvest insect disinfestation (Aharoni et al., 1979; Lidster et al., 1981, 1984; Soderstrom and Brandl, 1987). CA treatments can be used for quarantine procedures only when the fresh commodities can tolerate the low- $\mathrm{O}_{2}$ and/or high- $\mathrm{CO}_{2}$ conditions longer than the insects. Through studying the physiological processes that limit the tolerance of fruits to low- $\mathrm{O}_{2}$ and/or high- $\mathrm{CO}_{2}$ atmospheres and predicting the tolerance of fruits and insects to CA conditions, the optimum CA treatments that will effectively kill the insects of concern without detrimental effects on the fruits can be selected.

In this paper, we report on the physiological processes and factors that determine the tolerance of fresh fruits to low- $\mathrm{O}_{2}$ atmospheres and present a mathematical model that predicts the tolerance of fruits to stress-inducing low- $\mathrm{O}_{2}$ conditions.

\section{Materials and Methods}

Materials and treatments. Fruits of 'Granny Smith' and 'Yellow Newtown' apples (both waxed), '20th Century' pear (nonwaxed), and 'Angeleno' plum (waxed) were obtained on the day of harvest from commercial shippers in San Joaquin, Monterey, Solano, and Fresno Counties of California, respectively, and transported in an air-conditioned car to our laboratory at the Univ. of California, Davis, where they were kept overnight at $0 \mathrm{C}$. The experiments were initiated the next morning. Fruits with defects were sorted out and discarded, and six good fruits 
were put into a 4- or 8-liter glass jar as one replicate, with three replicates used per treatment in a flow system. In one set of experiments, the fruit samples were kept in humidified air, $0.25 \%$ $\mathrm{O}_{2}$, or $0.02 \% \mathrm{O}_{2}$ (balance was $\mathrm{N}_{2}$ ) at 0,5 , or $10 \mathrm{C}$ for 3 days before they were used for the determinations of respiration and ethylene production rates, internal $\mathrm{CO}_{2}$ concentration, and resistance to gas diffusion. In another set of experiments, the fruit samples were kept in the stated atmospheres at 0,5 , or $10 \mathrm{C}$ for $7,14,25$, or 35 days followed by holding in air for 7 days to allow the ethanol content to decrease at 0C (for 'Granny Smith' apple, '20th Century' pear, and 'Angeleno' plum) or 5C (for 'Yellow Newtown' apple). Then the fruits were transferred to air at 20C for 2 to several days to allow them to ripen before final quality evaluations.

Gas measurements. The $\mathrm{O}_{2}$ and $\mathrm{CO}_{2}$ concentrations of all gas mixtures were measured by analysis of a 10-ml gas sample using an $\mathrm{O}_{2}$ analyzer (Model S-3All, Applied Electrochemistry, Sunnyvale, Calif.) in series with an infrared $\mathrm{CO}_{2}$ analyzer (Model PIR-2000, Horiba Instruments, Irvine, Calif.). Respiration rate was estimated by detecting the $\mathrm{CO}_{2}$ concentration from the headspace of the jar holding the fruits, the flow rate used, and the fresh weight of the sample. The vacuum extraction method (Saltveit, 1982) was used to determine internal $\mathrm{CO}_{2}$ concentration and resistance to gas diffusion. The vacuum apparatus consisted of a steel vessel and a heavy-duty funnel with a plastic gas-sampling septum attached to the tip of the funnel. The funnel was placed inside the vessel, which was filled to the top with degassed water. Six fruits were placed under water in the inverted funnel. The vessel was closed and a vacuum of $\approx 2300$ $\mathrm{kPa}$ applied. Preliminary experiments showed that the extracted interal gas concentrations did not significantly change over 1 to 5 min under the vacuum and, therefore, a 3-min vacuum time was used in the experiments. The vacuum was then released and the vessel opened. Samples were taken through the septum using a 1-ml syringe for the determination of internal $\mathrm{CO}_{2}$ concentration. Resistance to $\mathrm{CO}_{2}$ diffusion was calculated by the ratio: $\left[\left(\mathrm{CO}_{2}\right)_{\text {Int. }}-\left(\mathrm{CO}_{2}\right)_{\text {Ext. }}\right] / \mathrm{CO}_{2}$ production rate (Trout et al., 1942). Ethylene production rate was estimated by detecting the ethylene concentration of the gas sample from each jar using a Carle gas chromatography (Model 211, Carle; EG \& G Chandler Engineering, Tulsa, Okla.) with a flame ionization detector, the flow rate used, and the fresh weight of the sample.

Determinations of quality attributes. Three initial samples of six fruits each were evaluated for external appearance, skin color, flesh firmness, SSC, $\mathrm{pH}$, titratable acidity, ethanol concentration, and flavor score. Similar measurements were done in the final quality evaluations. External appearance was scored using a subjective scale of 1 to 5 , where $5=$ excellent, $4=$ good, 3 = fair, 2 = slight defects, $1=$ severe defects. Skin color was measured with a Gardner XL-23 Tristimulus Calorimeter (Gardner Laboratory, Bethesda, Md.) using the color difference meter (CDM) "a" value in which a more negative number means increasing greenness, while a larger positive number indicates increasing redness. Flesh firmness was measured as penetration force with a Univ. of California fruit firmness tester, using an 11-mm plunger tip for apples and an 8-mm tip for pears and plums. Fruit juice was extracted from four flesh sections of each fruit with a hand-press juicer. SSC was measured with an Abbé refractometer (VWR Scientific, San Francisco), and $\mathrm{pH}$ and titratable acidity were measured using an automatic titrator with a PHM85 Precision pH meter (Radiometer, Copenhagen, Denmark), an AUB80 autoburette (Radiometer), a PRS12 Alpha printer (Radiometer), and a SAC80 sample changer (Radiometer).
Determination of ethanol content. Frozen fruit juice was thawed and a 2-ml sample was diluted with $18 \mathrm{ml}$ deionized water. The diluted sample was centrifuged at $25,000 \times g$ for $20 \mathrm{~min}$ at $0 \mathrm{C}$, and then $\approx 2 \mathrm{ml}$ supernatant was filtered through a $0.45-\mu \mathrm{m}$ microfilter in a $0 \mathrm{C}$ room. The filtrate was used for the determination of ethanol concentration using a HP5890A gas chromatography (Hewlett Packard, Palo Alto, Calif.) with a flame ionization detector (at 250C) and a glass column $(2 \mathrm{~mm} \times 1.8$ m) containing 5\% Carbowax on 60/80 Carpoback (at 85C).

Estimation of low- $\mathrm{O}_{2}$ injury. Low- $\mathrm{O}_{2}$ injury was estimated by a pretransformed scale of 1 to 5 according to the percentage of brown area in the core and/or flesh of a longitudinal fruit section: $1=$ no injury; 2 = slight injury, up to $15 \%$ browning; $3=$ moderate injury, $16 \%$ to $50 \%$ browning; $4=$ severe injury, $51 \%$ to $85 \%$ browning; $5=$ extreme injury, $86 \%$ to $100 \%$ browning.

Estimation of flavor score. Flavor score was estimated by tasting using a subjective scale ranging from 1 to 7 , where $7=$ excellent, 6 = good, 5 = fair, $4=$ slight off-flavor, $3=$ moderate off-flavor, 2 = severe off-flavor, 1 = extreme offflavor. Three fruits were tested in each treatment, with one section tasted in each fruit. The evaluation was done in the Postharvest Laboratory, Pomology Dept. The judge rinsed adlib with drinking water between tastings to clear his mouth of residual samples and to avoid an influence by prior fruits. Previous studies with strawberries and oranges used an untrained taste panel of $\approx 100$ people and a trained taste panel of four people to conduct sensory evaluations (Ke and Kader, 1990; Ke et al., 1991). D.K. participated in such studies and gained substantial experience in sensory evaluation; due to the limited resources available, only he estimated flavor in this research. This approach reduced the variation in the ability to detect offflavor, but potentially limited the reproducibility of the results.

Statistical analysis. Data were treated for multiple comparisons by analysis of variance with least significant difference (LSD) between means determined at $P=0.05$. A computer curve fit program (Cricket Graph, Macintosh SE, Apple Computer, Cupertino, Calif.) was used to analyze the regression and correlation between ethanol content and flavor score.

\section{Results}

Storage of 'Granny Smith' apples in $0.25 \%$ or $0.02 \% \mathrm{O}_{2}$ at 0 or $10 \mathrm{C}$ generally slightly reduced respiration and ethylene production rates but increased internal $\mathrm{CO}_{2}$ concentration and resistance to $\mathrm{CO}_{2}$ diffusion (Table 1). Respiration and ethylene production rates and internal $\mathrm{CO}_{2}$ concentration were higher at $10 \mathrm{C}$ than those at $0 \mathrm{C}$, but resistance to $\mathrm{CO}_{2}$ diffusion was lower at the higher temperature. The low- $\mathrm{O}_{2}$ treatments did not significantly influence skin color, flesh firmness, and external appearance of 'Granny Smith' apples during the experimental period but slightly retarded the reduction in titratable acidity. As acidity decreased, $\mathrm{pH}$ slightly increased in all treatments (Table 1). No visible injury or decay was observed in any of the treatments during the experiment. The low- $\mathrm{O}_{2}$ treatments did not influence SSC but greatly increased ethanol content (EC) and reduced the flavor score of 'Granny Smith' apples (Fig. 1). The low- $\mathrm{O}_{2}$ effects were more pronounced at $10 \mathrm{C}$ than those at $0 \mathrm{C}$. The effects of 0.029002 were greater than those of $0.25 \% \mathrm{O}_{2}$. Flavor scores of 4 or below indicate that alcoholic off-flavor could be detected in low- $\mathrm{O}_{2}$-treated fruits.

Exposure of 'Yellow Newtown' apples to $0.25 \%$ or $0.02 \%$ $\mathrm{O}_{2}$ at 5 or $10 \mathrm{C}$ increased $\mathrm{CO}_{2}$ production rate, internal $\mathrm{CO}_{2}$ concentration, and resistance to $\mathrm{CO}_{2}$ diffusion (Table 2). Res- 
Table 1. Effects of $\mathrm{O}_{2}$ level and temperature on respiration and ethylene production rates, internal $\mathrm{CO}_{2}$ concentration, resistance to $\mathrm{CO}_{2}$ diffusion $\left(\mathrm{r}_{\mathrm{CO}_{2}}\right)$, and quality attributes of 'Granny Smith' apples. Skin color, flesh firmness, external appearance, titratable acidity, and $\mathrm{pH}$ were measured after specified days under treatment followed by holding in air at $0 \mathrm{C}$ for 7 days and then at $20 \mathrm{C}$ for 7 days.

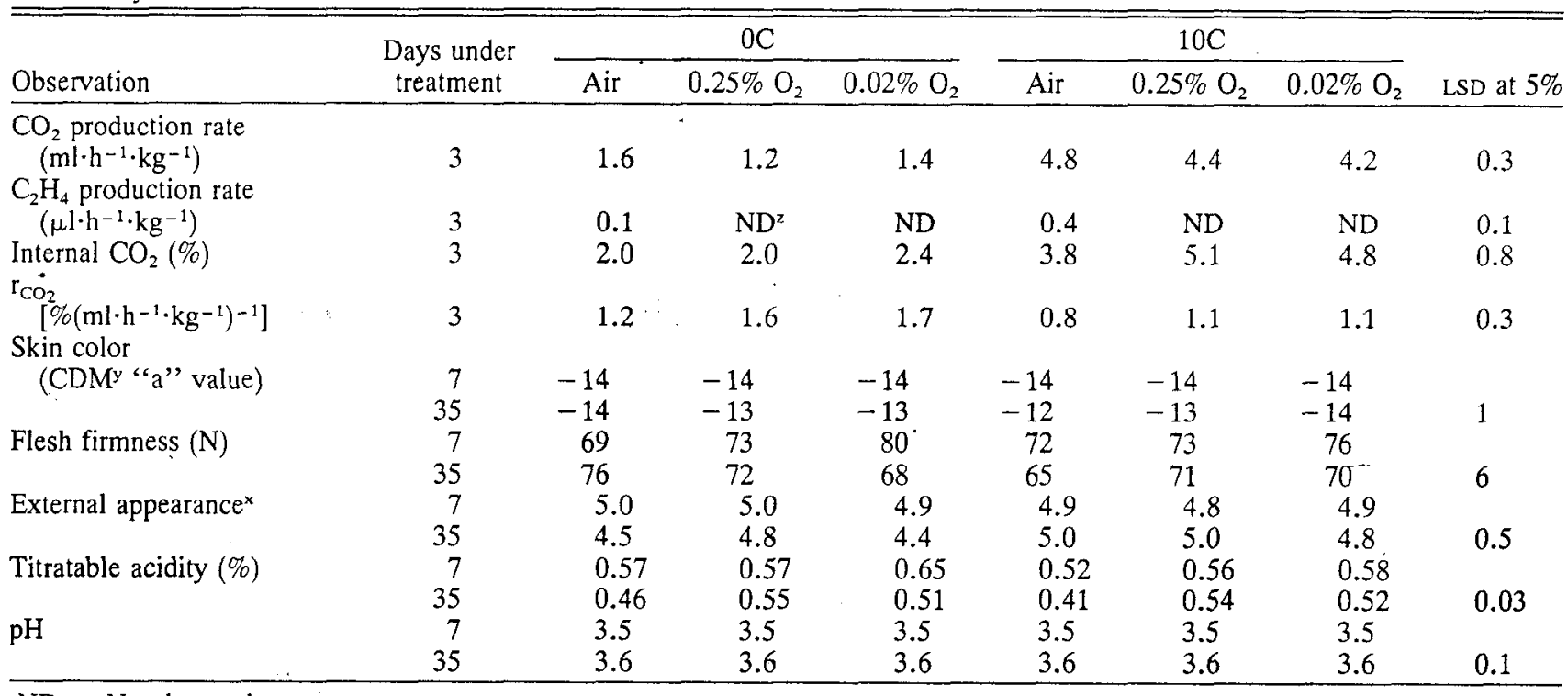

${ }^{2} \mathrm{ND}=$ Not detected.

" $\mathrm{CDM}=$ color difference meter; a more negative " $\mathrm{a}$ " value indicates a greener appearance.

${ }^{x}$ Estimated using a scale of 1 to 5 , where $5=$ excellent, $4=$ good, $3=$ fair, $2=$ slight defects, and $1=$ severe defects.
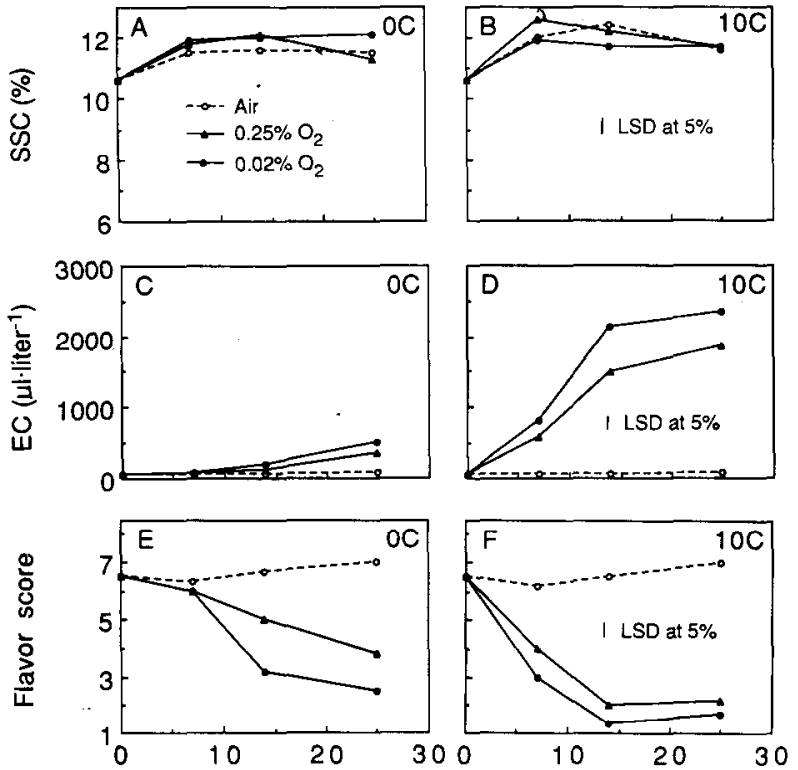

Days under treatment

Fig. 1. Effects of $\mathrm{O}_{2}$ level and temperature on the soluble solids content (SSC), ethanol content (EC), and flavor score of "Granny Smith' apples kept in air, $0.25 \% \mathrm{O}_{2}$, or $0.02 \% \mathrm{O}_{2}$ at 0 or $10 \mathrm{C}$ for 7,14 , or 25 days followed by holding in air at $\mathrm{OC}$ for 7 days and then at $20 \mathrm{C}$ for 7 days. Flavor score was estimated using a scale of 1 to 7 , where $7=$ excellent, $6=$ good, $5=$ fair, $4=$ slight offflavor, 3 = moderate off-flavor, 1 = extreme off-flavor.

piration rate and internal $\mathrm{CO}_{2}$ concentration were higher in fruits at $10 \mathrm{C}$ than in those at $5 \mathrm{C}$, while resistance to $\mathrm{CO}_{2}$ diffusion was lower at 10C. No ethylene production was detected in 'Yellow Newtown' apples from any treatment in this experiment. The low $-\mathrm{O}_{2}$ treatments slightly retarded skin yellowing, flesh softening, and decreases in titratable acidity of the fruits, but external appearance and $\mathrm{pH}$ were not significantly influenced (Table 2). No visible injury or decay was observed during the experiment. Treatments with $0.25 \%$ or $0.02 \% \mathrm{O}_{2}$ did not significantly affect SSC but greatly increased the ethanol content and reduced the flavor score of 'Yellow Newtown' apples (Fig. 2 ). The effects at $10 \mathrm{C}$ were greater than those at $5 \mathrm{C}$.

Storage of '20th Century' pears in $0.25 \%$ or $0.02 \% \mathrm{O}_{2}$ at 0 or $5 \mathrm{C}$ generally decreased respiration rate but decreased internal $\mathrm{CO}_{2}$ concentration consistently only at $0 \mathrm{C}$ and increased resistance to $\mathrm{CO}_{2}$ diffusion (Table 3). No ethylene production was detected in '20th Century' pears from any treatment. Skin color, flesh firmness, and external appearance of the fruits were not significantly influenced by the low- $\mathrm{O}_{2}$ treatments. Exposure of '20th Century' pears to $0.25 \%$ or $0.02 \% \mathrm{O}_{2}$ at 0 or $5 \mathrm{C}$ for 7 days did not cause any visible injury; but longer exposures (14 to 35 days) resulted in core browning. This result indicates that '20th Century' pears were sensitive to low- $\mathrm{O}_{2}$ injury. The low$\mathrm{O}_{2}$ atmospheres did not have consistent effects on titratable acidity and $\mathrm{pH}$ of the fruits (Table 3 ). No decay was observed during the experiment. The low- $\mathrm{O}_{2}$ treatments at 0 or $5 \mathrm{C}$ did not significantly influence SSC but greatly increased ethanol content and decreased the flavor score of '20th Century' pears (Fig. 3). Generally, the effects of low- $\mathrm{O}_{2}$ treatments were more pronounced at $5 \mathrm{C}$ than at $0 \mathrm{C}$; and the effects of $0.02 \% \mathrm{O}_{2}$ were greater than those of $0.25 \% \mathrm{O}_{2}$.

Exposure to $0.25 \%$ or $0.02 \% \mathrm{O}_{2}$ at 5 or $10 \mathrm{C}$ reduced respiration and ethylene production rates but increased resistance to $\mathrm{CO}_{2}$ diffusion of 'Angeleno' plums (Table 4); internal $\mathrm{CO}_{2}$ concentration was not significantly influenced by the low $-\mathrm{O}_{2}$ treatments. Respiration and ethylene production rates and internal $\mathrm{CO}_{2}$ concentration were higher at $10 \mathrm{C}$ than at $5 \mathrm{C}$, while resistance to $\mathrm{CO}_{2}$ diffusion was lower at the higher temperature. As the plums ripened, skin color changed from red to dark red (lower "a" values) and flesh firmness decreased. The low- $\mathrm{O}_{2}$ 
Tablc 2. Effects of $\mathrm{O}_{2}$ lcvel and tempcraturc on respiration rate, internal $\mathrm{CO}_{2}$ concentration, resistance to $\mathrm{CO}_{2}$ diffusion ( $\mathrm{r}_{2}$ ), and quality attributes of 'Yellow Newtown' apples. Skin color, flesh firmness, external appearance, titratable acidity, and $\mathrm{pH}$ were measured after specified days under treatment followed by holding in air at $5 \mathrm{C}$ for 7 days and then at $20 \mathrm{C}$ for 14 days.

\begin{tabular}{|c|c|c|c|c|c|c|c|c|}
\hline \multirow[b]{2}{*}{ Observation } & \multirow{2}{*}{$\begin{array}{l}\text { Days under } \\
\text { treatment }\end{array}$} & \multicolumn{3}{|c|}{$5 \mathrm{C}$} & \multicolumn{3}{|c|}{$10 \mathrm{C}$} & \multirow[b]{2}{*}{ LSD at $5 \%$} \\
\hline & & Air & $0.25 \% \mathrm{O}_{2}$ & $0.02 \% \mathrm{O}_{2}$ & Air & $0.25 \% \mathrm{O}_{2}$ & $0.02 \% \mathrm{O}_{2}$ & \\
\hline \multicolumn{9}{|l|}{$\mathrm{CO}_{2}$ production rate } \\
\hline Internal $\mathrm{CO}_{2}(\%)$ & 3 & 5.3 & 7.6 & 8.0 & 6.1 & 9.6 & 11.4 & 1.0 \\
\hline$\left[\mathrm{CO}_{2} \% \cdot\left(\mathrm{ml}^{\mathrm{r}} \cdot \mathrm{h}^{-1} \cdot \mathrm{kg}^{-1}\right)^{-1}\right]$ & 3 & 1.7 & 2.0 & 2.2 & 1.1 & 1.5 & 1.8 & 0.2 \\
\hline \multicolumn{9}{|l|}{ Skin color } \\
\hline (CDM"z “a”value) & $\begin{array}{r}7 \\
35\end{array}$ & $\begin{array}{l}-14 \\
-11\end{array}$ & $\begin{array}{l}-13 \\
-12\end{array}$ & $\begin{array}{l}-13 \\
-13\end{array}$ & $\begin{array}{r}-13 \\
-9\end{array}$ & $\begin{array}{l}-13 \\
-12\end{array}$ & $\begin{array}{l}-13 \\
-11\end{array}$ & 1 \\
\hline \multirow[t]{2}{*}{ Flesh firmness (N) } & 7 & 99 & 102 & 100 & 104 & 99 & 103 & \\
\hline & 35 & 73 & 81 & 79 & 70 & 92 & 89 & 9 \\
\hline \multirow{2}{*}{ External appearance $y$} & 7 & 4.6 & 4.2 & 4.1 & 4.2 & 4.6 & 4.5 & \\
\hline & 35 & 4.2 & 4.4 & 4.3 & 4.3 & 4.6 & 4.0 & 0.8 \\
\hline \multirow[t]{2}{*}{ Titratable acidity $(\%)$} & 7 & 0.56 & 0.52 & 0.54 & 0.54 & 0.52 & 0.55 & \\
\hline & 35 & 0.39 & 0.42 & 0.42 & 0.36 & 0.42 & 0.38 & 0.03 \\
\hline \multirow[t]{2}{*}{$\mathrm{pH}$} & 7 & 3.6 & 3.6 & 3.6 & 3.6 & 3.6 & 3.6 & \\
\hline & 35 & 3.7 & 3.7 & 3.7 & 3.8 & 3.7 & 3.8 & 0.1 \\
\hline
\end{tabular}

${ }^{\mathrm{z}} \mathrm{CDM}=$ color difference meter; a more negative " $\mathrm{a}$ " value indicates a greener appearance.

yEstimated using a scale of 1 to 5 , where $5=$ excellent, $4=$ good, $3=$ fair, $2=$ slight defects, and $1=$ severe defects.
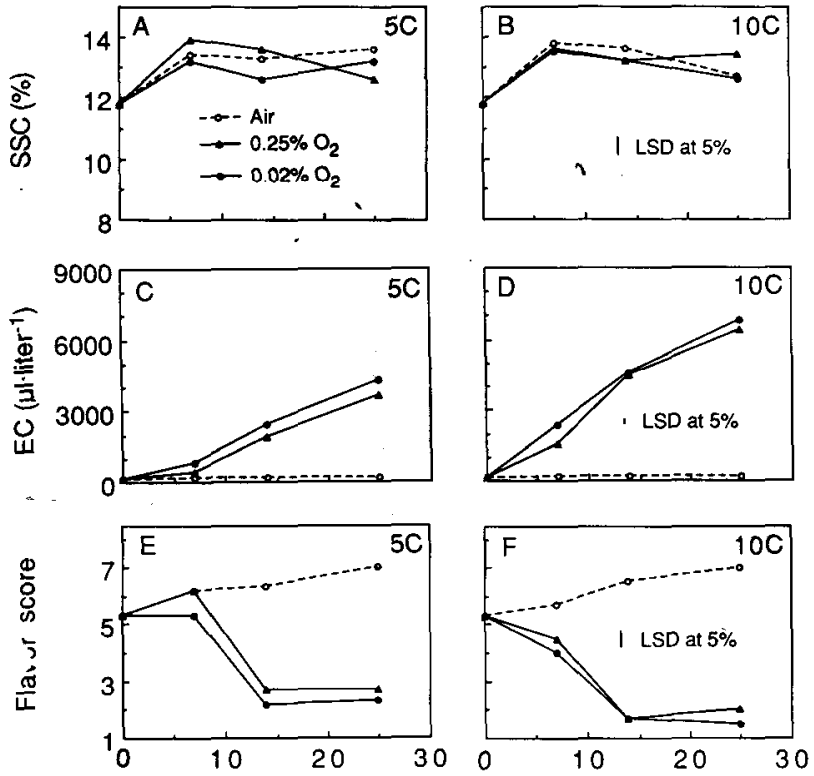

Days under treatment

Fig. 2. Effects of $\mathrm{O}_{2}$ level and temperature on soluble solids content (SSC), ethanol content (EC), and flavor score of 'Yellow Newtown' apples kept in air, $0.25 \% \mathrm{O}_{2}$, or $0.02 \% \mathrm{O}_{2}$ at 5 or $10 \mathrm{C}$ for 7,14 , or 25 days followed by holding in air at $5 \mathrm{C}$ for 7 days and then at $20 \mathrm{C}$ for 14 days. Flavor score was estimated using a scale of 1 to 7 (see legend of Fig. 1 for details).

treatments retarded skin color changes at both 5 and 10C, but the retardation effect on flesh softening was noted only at $10 \mathrm{C}$ (Table 4). External appearance, titratable acidity, and $\mathrm{pH}$ of the plums were not consistently influenced by the low- $\mathrm{O}_{2}$ treatments. No visual low- $\mathrm{O}_{2}$ injury was observed and decay was negligible during the experiment. The low- $\mathrm{O}_{2}$ treatments did not significantly influence SSC but dramatically increased ethanol content and decreased flavor score of the plums (Fig. 4). The effects were more pronounced at $10 \mathrm{C}$ or in $0.02 \% \mathrm{O}_{2}$ than at $5 \mathrm{C}$ or in $0.25 \% \mathrm{O}_{2}$.

\section{Discussion}

The major beneficial effects of short-term exposure to $0.25 \%$ or $0.02 \% \mathrm{O}_{2}$ were the inhibition or delay of ripening processes, including reduction in respiration and/or ethylene production rates; retardation of skin color changes and flesh softening; and maintenance of acidity in the fruits. External appearance, $\mathrm{pH}$, and SSC were not significantly influenced by the low- $\mathrm{O}_{2}$ treatments. For all the fruits tested thus far, including apples, Asian pears, 'Bartlett' pears (Ke et al., 1990), nectarines (Kerbel et al., 1989), peaches, plums, strawberries (Ke et al., 1991), and 'Valencia' oranges (Ke and Kader, 1990), '20th Century' pear is the only one in which visible low- $\mathrm{O}_{2}$ injury was observed during short-term exposure to low $\mathrm{O}_{2}$ levels. However, alcoholic off-flavor was detected in the low- $\mathrm{O}_{2}$-treated fruits of all the commodities after various durations during the experiments. Therefore, the occurrence of an alcoholic off-flavor is the most important detrimental effect with short-term low- $\mathrm{O}_{2}$ treatments. A low- $\mathrm{O}_{2}$-treated fruit may look good but taste bad. Thus, the tolerance of fresh fruits to short-term low- $\mathrm{O}_{2}$ atmospheres is largely limited by the occurrence of off-flavor.

After the flavor score decreased to 4 (slight off-flavor) or a lower value, the flavor was not acceptable. Therefore, the number of days to reach a flavor score of 4 was used as the tolerance limit of fruits to low- $\mathrm{O}_{2}$ atmospheres from the experiments $\left(\mathrm{T}_{1} \mathrm{e}\right)$. The $T_{1}$ values for all treatments of the four commodities were obtained from Figs. 1-4 by linear extrapolation and are presented in Table 5. For each commodity, $\mathrm{T}_{1} \mathrm{e}$ was higher at the higher $\mathrm{O}_{2}$ concentration and lower at the higher temperature.

The accumulation of ethanol was accompanied by a decrease in the flavor score of the four commodities tested in this study (Figs. 1-4). A computer curve fit program (including linear, polynomial, logarithmic, and exponential regressions) was used to analzye the correlation between ethanol content and flavor score; the best curve fit was obtained by the logarithmic regression (Fig. 5). The correlation coefficients $(r)$ were 0.93 to 0.94 for the four commodities. When the ethanol content data were transformed to a Log scale, straight lines were obtained from the correlation analysis. Therefore, ethanol content and flavor score, as related to ethanol content, have a logarithmic relation, 
Table 3. Effects of $\mathrm{O}_{2}$ level and temperature on respiration rate, internal $\mathrm{CO}_{2}$ concentration, resistance to $\mathrm{CO}_{2}$ diffusion ( $\mathrm{r}_{\mathrm{CO}_{2}}$ ), and quality attributes of '20th Century' pears. Skin color, flesh firmness, external appearance, titratable acidity, and pH were measured after specified days under treatment followed by holding in air at $0 \mathrm{C}$ for 7 days and then at $20 \mathrm{C}$ for 3 days.

\begin{tabular}{|c|c|c|c|c|c|c|c|c|}
\hline \multirow[b]{2}{*}{ Observation } & \multirow{2}{*}{$\begin{array}{c}\text { Days under } \\
\text { treatment }\end{array}$} & \multicolumn{3}{|c|}{$0 \mathrm{C}$} & \multicolumn{3}{|c|}{$5 \mathrm{C}$} & \multirow[b]{2}{*}{ LSD at $5 \%$} \\
\hline & & Air. & $0.25 \% \mathrm{O}_{2}$ & $0.02 \% \mathrm{O}_{2}$ & Air & $0.25 \% \mathrm{O}_{2}$ & $0.02 \% \mathrm{O}_{2}$ & \\
\hline \multicolumn{7}{|l|}{$\mathrm{CO}_{2}$ production rate } & 1.6 & 0.2 \\
\hline Internal $\mathrm{CO}_{2}(\%)$ & 3 & 0.35 & 0.23 & 0.26 & 0.48 & 0.39 & 0.46 & 0.12 \\
\hline $\begin{array}{l}\mathrm{r}_{\mathrm{CO}_{2}} \\
{\left[\% \cdot\left(\mathrm{ml} \cdot \mathrm{h}^{-1} \cdot \mathrm{kg}^{-1}\right)^{-1}\right]} \\
\text { Skin color }\end{array}$ & 3 & 0.14 & 0.23 & 0.21 & 0.14 & 0.21 & 0.24 & 0.05 \\
\hline (CDM"z “a” value) & 7 & -2.1 & -2.3 & -2.6 & -2.4 & -1.2 & -1.8 & \\
\hline Flesh firmness $(\mathrm{N})$ & $\begin{array}{r}35 \\
7\end{array}$ & $\begin{array}{c}-0.7 \\
32\end{array}$ & $\begin{array}{l}-2.4 \\
37\end{array}$ & $\begin{array}{c}-1.0 \\
37\end{array}$ & $\begin{array}{c}-0.2 \\
34\end{array}$ & $\begin{array}{c}-1.9 \\
32\end{array}$ & $\begin{array}{l}-2.6 \\
34\end{array}$ & 2.2 \\
\hline & 35 & 32 & 30 & 31 & 31 & 32 & 31 & 4 \\
\hline Internal injury severity & 7 & 1.0 & 1.2 & 1.0 & 1.0 & 1.2 & 1.0 & \\
\hline & 14 & 1.0 & 1.8 & 1.9 & 1.2 & 1.5 & 2.0 & 0.7 \\
\hline & 35 & 1.0 & 3.1 & 3.2 & 1.0 & 1.8 & 2.3 & \\
\hline External appearance ${ }^{x}$ & 7 & 5.0 & 5.0 & 5.0 & 5.0 & 5.0 & 5.0 & \\
\hline & 35 & 4.8 & 4.9 & 4.3 & 4.9 & 4.8 & 4.9 & 0.6 \\
\hline Titratable acidity (\%) & 7 & 0.22 & 0.25 & 0.25 & 0.24 & 0.21 & 0.21 & \\
\hline & 35 & 0.16 & 0.14 & 0.14 & 0.16 & 0.18 & 0.17 & 0.03 \\
\hline $\mathrm{pH}$ & 7 & 4.4 & 4.3 & 4.4 & 4.3 & 4.4 & 4.4 & \\
\hline & 35 & 4.6 & 4.6 & 4.7 & 4.5 & 4.5 & 4.6 & 0.1 \\
\hline
\end{tabular}

${ }^{2} \mathrm{CDM}=$ color difference meter; a more negative " $\mathrm{a}$ " value indicates a greener appearance.

'Estimated using a pretransformed scale of 1 to 5 according to the percentage of brown area in the longitudinal section: $1=$ no injury; 2 = slight injury, $1 \%$ to $15 \%$ brown area; $3=$ moderate injury, $16 \%$ to $50 \%$ brown area; $4=$ severe injury, $51 \%$ to $85 \%$ brown area; $5=$ extreme injury, $86 \%$ to $100 \%$ brown area.

Estimated using a scale of 1 to 5 , where $5=$ excellent, $4=$ good, $3=$ fair, $2=$ slight defects, and $1=$ sevcre defccts.
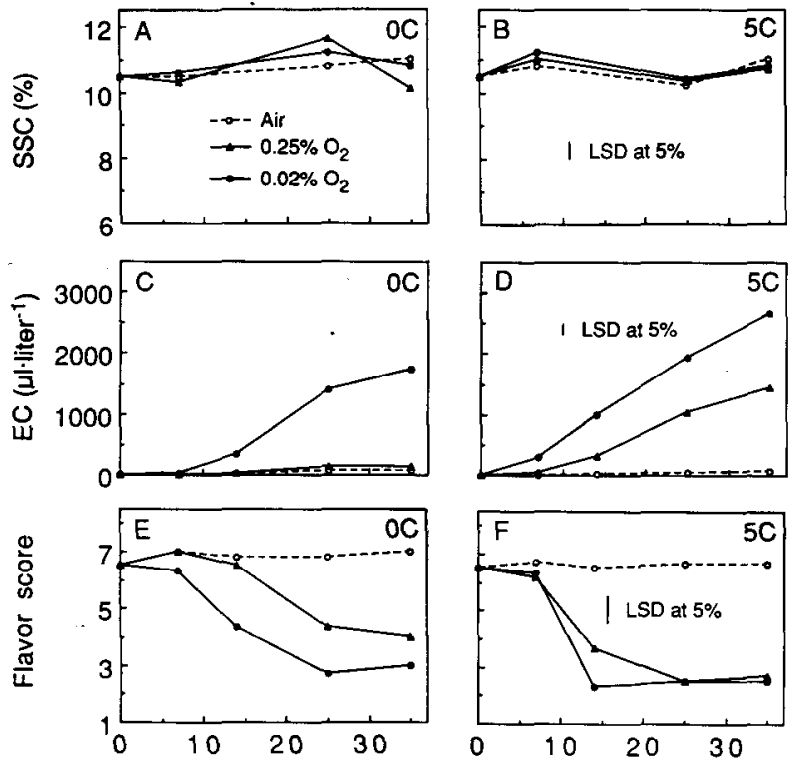

Days under treatment

Fig. 3. Effects of $\mathrm{O}_{2}$ level and temperature on soluble solids content (SSC), ethanol content (EC), and flavor score of ' 20 th Century' pears kept in air, $0.25 \% \mathrm{O}_{2}$, or $0.02 \% \mathrm{O}_{2}$ at 0 or $5 \mathrm{C}$ for $7,14,25$, or 35 days followed by holding in air at $0 \mathrm{C}$ for 7 days and then at $20 \mathrm{C}$ for 3 days. Flavor score was estimated using a scale of 1 to 7 (see legend of Fig. 1 for details).

While it is well-known that the accumulation of ethanol may cause off-flavor in fruits and vegetables, the ethanol concentrations that cause alcoholic off-flavors varied greatly among commodities. For example, an ethanol content $>200 \mu l \cdot$ liter $^{-1}$ caused a slight off-flavor (a flavor score of 4) in '20th Century' pears (Fig. 3), but it took $>1000$ and $2000 \mu \mathrm{l}$ ethanol/liter to cause a slight off-flavor in 'Yellow Newtown' apples (Fig. 2) and 'Angeleno' plums (Fig. 4), respectively.

The variation in the threshold ethanol concentration causing off-flavor among commodities may be due to the interaction between ethanol and other compounds (such as sugars and organic acids). Using the data from Figs. 1-4 to analyze the relationship between SSC and the ethanol content causing slight off-flavor $\left(E_{\mathrm{o}}\right)$ in apples, 'Asian' pears, and plums, we found higher SSC to generally require higher ethanol concentrations to cause slight off-flavor (Fig. 6A). Since the relationship between ethanol content and flavor score is logarithmic (Fig. 5), the $\mathrm{E}_{\mathrm{o}}$ data were transformed to a $\log$ scale. The ratio of ( $\mathrm{Log}$ $\mathrm{E}_{\mathrm{o}}$ )/SSC is very constant (with a standard deviation of 0.019 ) for all low $-\mathrm{O}_{2}$ treatments of the four commodities (Fig. 6B):

$$
\left(\log \mathrm{E}_{\mathrm{o}}\right) / \mathrm{SSC}=0.228
$$

Thus, SSC plays a very important role in determining the ethanol level that causes off-flavor. SSC probably provides a background flavor for the interaction with ethanol; the higher the SSC, the higher the ethanol content required to cause offflavor in the fruits. It is still not clear if this effect is due to a specific component of SSC, since SSC represents all the compounds from the fruits that are soluble in water.

From Eq. [1], the ethanol content causing slight off-flavor could be estimated from SSC of ripe fruits for all the commodities tested as follows:

$$
\mathrm{E}_{\mathrm{o}}=10^{0.228 \mathrm{ssc}}
$$

From the estimated ethanol content causing slight off-flavor in Eq. [2] and the calculated average ethanol accumulation rate per day $\left(\mathrm{V}_{\mathrm{E}}\right)$ of fruits under a low- $\mathrm{O}_{2}$ treatment, the tolerance 
Table 4. Effects of $\mathrm{O}_{2}$ level and temperature on respiration and ethylene production rates, internal $\mathrm{CO}_{2}$ concentration, resistance to $\mathrm{CO}_{2}$ diffusion $\left(\mathrm{I}_{\mathrm{CO}_{2}}\right)$, and quality attributes of 'Angeleno' plum. Skin color, flesh firmness, external appearance, titratable acidity, and $\mathrm{pH}$ were measured after specified days under treatment followed by holding in air at $0 \mathrm{C}$ for 7 days and then at $20 \mathrm{C}$ for 2 days.

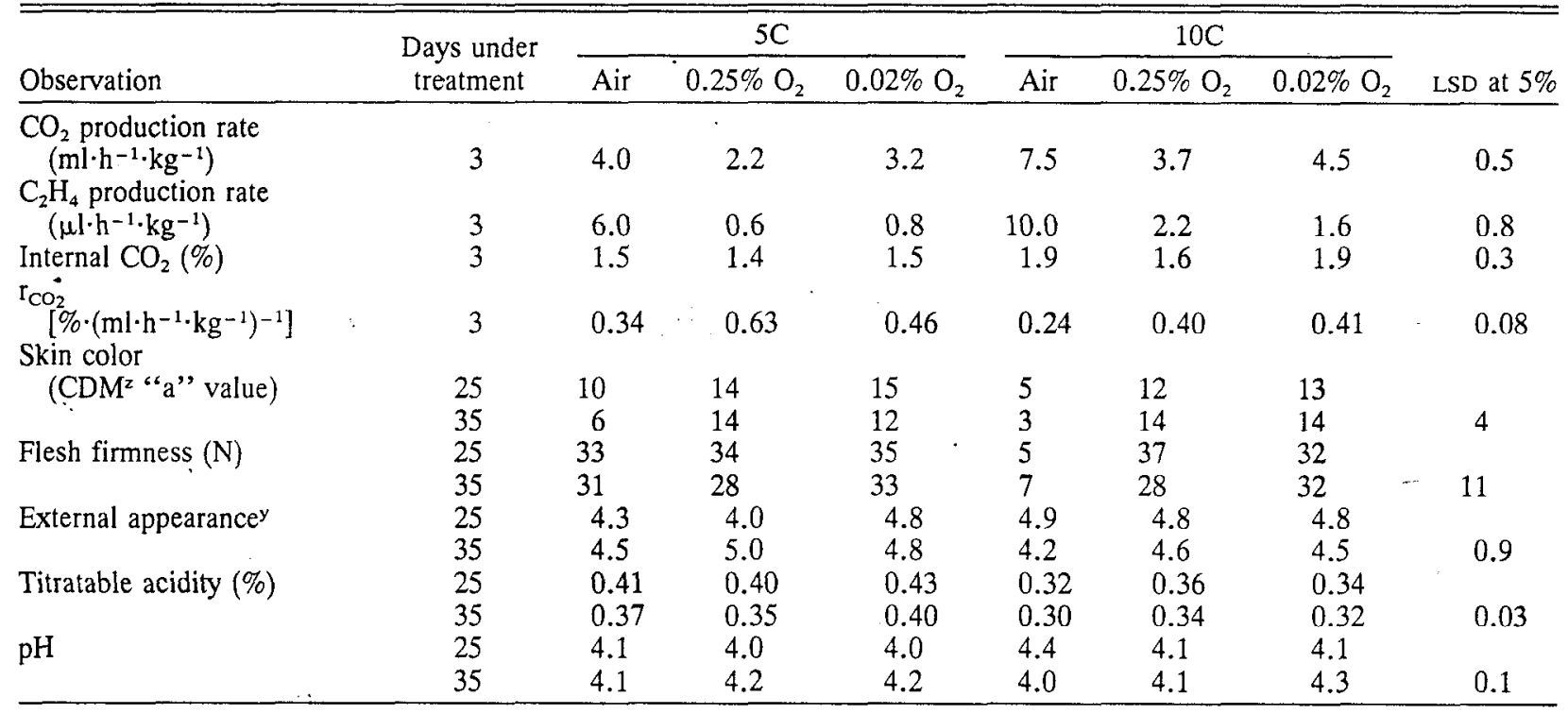

${ }^{z} \mathrm{CDM}=$ color difference meter; a darker red resulted in a lower "a" value.

${ }^{y}$ Estimated using a scale of 1 to 5 , where $5=$ excellent, $4=$ good, $3=$ fair, $2=$ slight defects, and $1=$ severe defects.
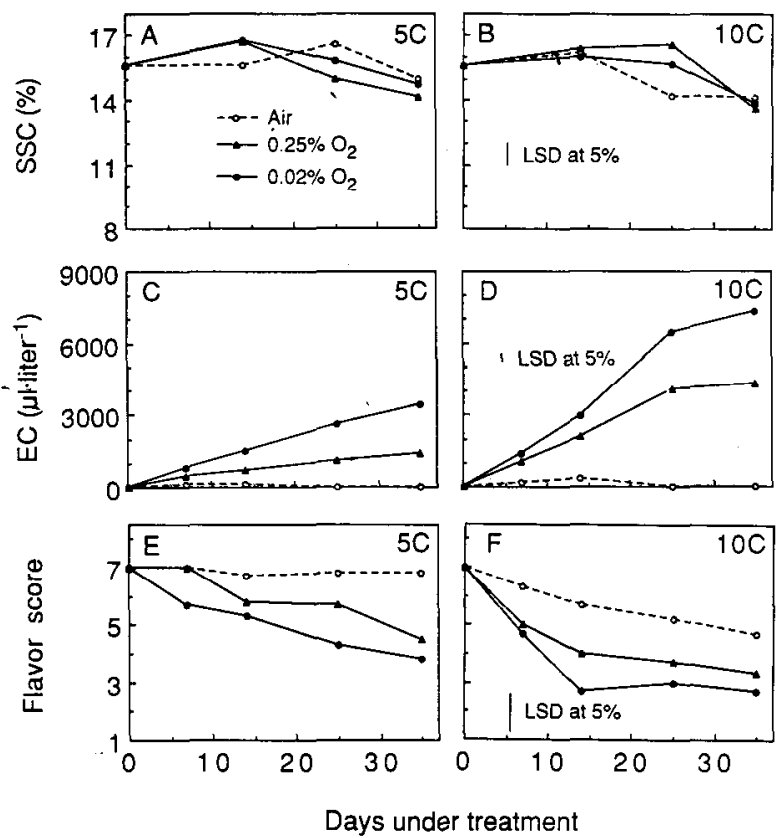

Fig. 4. Effects of $\mathrm{O}_{2}$ level and temperature on soluble solids content (SSC), ethanol content (EC), and flavor score of 'Angeleno' plums kept in air, $0.25 \% \mathrm{O}_{2}$, or $0.02 \% \mathrm{O}_{2}$ at 5 or $10 \mathrm{C}$ for $7,14,25$, or 35 days followed by holding in air at $0 \mathrm{C}$ for 7 days and then at $20 \mathrm{C}$ for 2 days. Flavor score was estimated using a scale of 1 to 7 (see legend of Fig. 1 for details).

limit $\left(\mathrm{T}_{1}\right)$ of fruits to low- $\mathrm{O}_{2}$ atmospheres can be predicted by:

$$
\mathrm{T}_{1}=\mathrm{E}_{\mathrm{o}} / \mathrm{V}_{\mathrm{E}}=\left(\begin{array}{ll}
1 & 0^{0.228 \mathrm{ssc}}
\end{array}\right) / \mathrm{V}_{\mathrm{E}}
$$

where $T_{1}=$ tolerance limit predicted, i.e., the number of days to cause slight off-flavor; $E_{0}=$ the ethanol content $\left(\mu l \cdot\right.$ liter $\left.^{-1}\right)$ of the fruit that causes slight off-flavor; $V_{E}=$ the average ethanol accumulation rate $\left(\mu \mathrm{l} \cdot \mathrm{liter}^{-1} \cdot \mathrm{day}^{-1}\right)$ of the fruit under the low $-\mathrm{O}_{2}$ treatment; and $\mathrm{SSC}=$ soluble solids content $(\%)$ of the fruit when ripe.

According to Eq. [3], two primary factors determine the tolerance of fruits to low- $\mathrm{O}_{2}$ atmospheres: $\mathrm{SSC}$ of ripe fruits and average ethanol accumulation rate of the fruits under the low$\mathrm{O}_{2}$ treatment. Other factors may affect fruit tolerance to low $\mathrm{O}_{2}$ through influencing these two primary factors. SSC of harvested ripe fruits is not greatly influenced by the $\mathrm{O}_{2}$ level or temperature used during these short storage treatments (Figs. 1-4). Cultural conditions before harvest and fruit maturity at harvest may influence SSC of the fruit when ripe. However, ethanol accumulation rate can be greatly influenced by several factors including the following:

1) Respiration rate of the fruits under a low- $\mathrm{O}_{2}$ treatment: $V_{E}$ generally increases as respiration rate increases since, under the low $\mathrm{O}_{2}$ levels $(0.25 \%$ to $0.02 \%)$, respiration is largely anaerobic, which produces much ethanol. Respiration rate is commodity-specific and may be influenced by the $\mathrm{O}_{2}$ level and temperature used.

2) $\mathrm{O}_{2}$ level used: ethanol accumulates at a higher rate at $0.02 \%$ than at $0.25 \% \mathrm{O}_{2}$ since anaerobic respiration rate is higher at the lower concentration.

3) Temperature used: as temperature increases, $\mathrm{O}_{2}$ consumption rate and respiration rate increase, which cause an increase in $\mathrm{V}_{\mathrm{E}}$.

4) Resistance to gas diffusion: this is largely commodityspecific, but it maybe influenced by postharvest treatment, such as waxing, which causes a great increase in resistance to gas diffusion. Under the same $\mathrm{O}_{2}$ level and temperature, a commodity with a higher resistance to gas diffusion will limit the efficiency of $\mathrm{O}_{2}$ use and the diffusion of ethanol out of the fruit, causing a higher $\mathrm{V}_{\mathrm{E}}$.

Equation [3] was used as a model to predict the tolerance of fruits to low $-\mathrm{O}_{2}$ atmospheres. Using the average SSC of the ripe fruits, $E_{\mathrm{O}}$ was estimated by Eq. [2]. $\mathrm{V}_{\mathrm{E}}$ values for all treatments 
Table 5. Comparison of tolerance limit from experiments $\left(T_{1} e\right)$ and predicted tolerance limit $\left(T_{1}\right)$ of ' $G r a n n y$ Smith' and 'Yellow Newtown' apples, '20th Century' pears, and 'Angeleno' plums to $0.25 \%$ or $0.02 \% \mathrm{O}_{2}$ at several temperatures. $T_{1}$ is predicted by the model $T_{1}=E_{\alpha} / V_{E}$ or $T_{1}=\left(10^{0.228 \mathrm{sSC}}\right) / V_{E}$, where $E_{0}$ is the predicted ethanol content causing slight off-flavor by using the average soluble solids content (SSC) of the commodity at the ripe stage and $V_{E}$ is the average ethanol accumulation rate of the fruits in the low- $\mathrm{O}_{2}$ treatment.

\begin{tabular}{|c|c|c|c|c|c|c|c|c|}
\hline Commodity & $\begin{array}{c}\text { Temp } \\
\left({ }^{\circ} \mathrm{C}\right) \\
\end{array}$ & $\begin{array}{c}\mathrm{O}_{2} \\
(\%) \\
\end{array}$ & $\begin{array}{l}\text { SSC } \\
(\%) \\
\end{array}$ & $\begin{array}{c}E_{o} \\
\left(\mu l \cdot \text { liter }^{-1}\right)\end{array}$ & $\begin{array}{c}V_{E} \\
\left(\mu l \cdot \text { liter }^{-1} \cdot \text { day }^{-1}\right)\end{array}$ & $\begin{array}{c}\mathrm{T}_{1} e^{\mathrm{e}} \\
\text { (days) } \\
\end{array}$ & $\begin{array}{c}T_{1} \\
\text { (days) }\end{array}$ & $\begin{array}{c}\mathrm{T}_{1} \mathrm{e}-\mathrm{T}_{1} \\
\text { (days) } \\
\end{array}$ \\
\hline \multirow[t]{4}{*}{ 'Granny Smith' apple } & 0 & 0.25 & 11.9 & 517 & 19 & 23.4 & 27.2 & -3.8 \\
\hline & 0 & 0.02 & 11.9 & 517 & 29 & 11.9 & 17.8 & -5.9 \\
\hline & 10 & 0.25 & 11.9 & 517 & 74 & 7.0 & 7.0 & 0.0 \\
\hline & 10 & 0.02 & 11.9 & 517 & 94 & 5.0 & 5.5 & -0.5 \\
\hline \multirow[t]{4}{*}{ 'Yellow Newtown' apple } & 5 & 0.25 & 13.4 & 1136 & 147 & 11.3 & 7.7 & 3.6 \\
\hline & 5 & 0.02 & 13.4 & 1136 & 173 & 9.9 & 6.6 & 3.3 \\
\hline & 10 & 0.25 & 13.4 & 1136 & 256 & 8.2 & 4.4 & 3.8 \\
\hline & 10 & 0.02 & 13.4 & 1136 & 272 & 7.0 & 4.2 & 2.8 \\
\hline \multirow[t]{4}{*}{ '20th Century' pear } & 0 & 0.25 & 10.7 & 275 & 8 & 35.0 & 34.4 & 0.6 \\
\hline & 0 & 0.02 & 10.7 & 275 & 24 & 16.2 & 11.7 & 4.5 \\
\hline & 5 & 0.25 & 10.7 & 275 & 22 & 13.1 & 12.4 & $-\quad 0.7$ \\
\hline & 5 & 0.02 & 10.7 & 275 & 40 & 11.0 & 6.8 & 4.2 \\
\hline \multirow[t]{4}{*}{ 'Angeleno' plum } & 5 & 0.25 & 15.3 & 3079 & 68 & 40.6 & 45.3 & -4.7 \\
\hline & 5 & 0.02 & 15.3 & 3079 & 96 & 31.6 & 32.1 & -0.5 \\
\hline & 10 & 0.25 & 15.3 & 3079 & 164 & 14.0 & 18.8 & -4.8 \\
\hline & 10 & 0.02 & 15.3 & 3079 & 259 & 9.4 & 11.9 & -2.5 \\
\hline
\end{tabular}
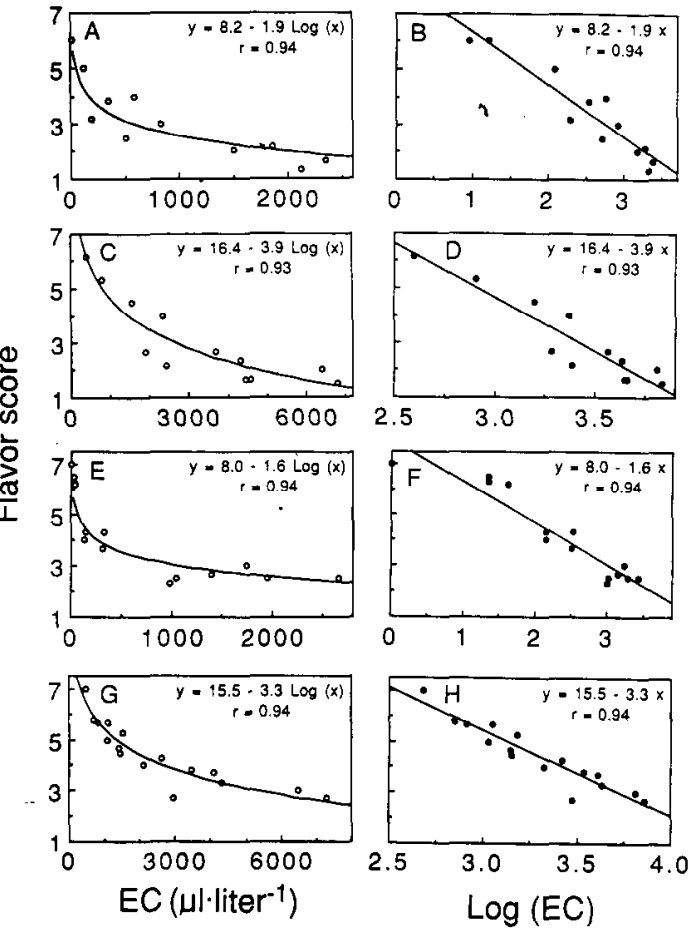

Fig. 5. Correlation between ethanol content (EC) and flavor score of low- $\mathrm{O}_{2}$-treated fruits of 'Granny Smith' (A and B) and 'Yellow Newtown' apples ( $\mathbf{C}$ and $\mathbf{D}$ ), '20th Century' pears ( $\mathbf{E}$ and $\mathbf{F}$ ), and 'Angeleno' plums ( $\mathbf{G}$ and $\mathbf{H}$ ). Flavor score was estimated using a scale of 1 to 7 (see legend of Fig. 1 for details).

of the four commodities during the first 1 to 2 weeks were calculated from Figs. 1-4. The tolerance limit $\left(T_{1} e\right)$ obtained from Figs. 1-4 of the experiments and the tolerance limit predicted by Eq. [3] $\left(\mathrm{T}_{1}\right)$ are quite close for most treatments (Table 5 ); the average deviation equals 2.9 days. Our later study on 'Bing' cherries (unpublished data) also indicated that Eq. [3]
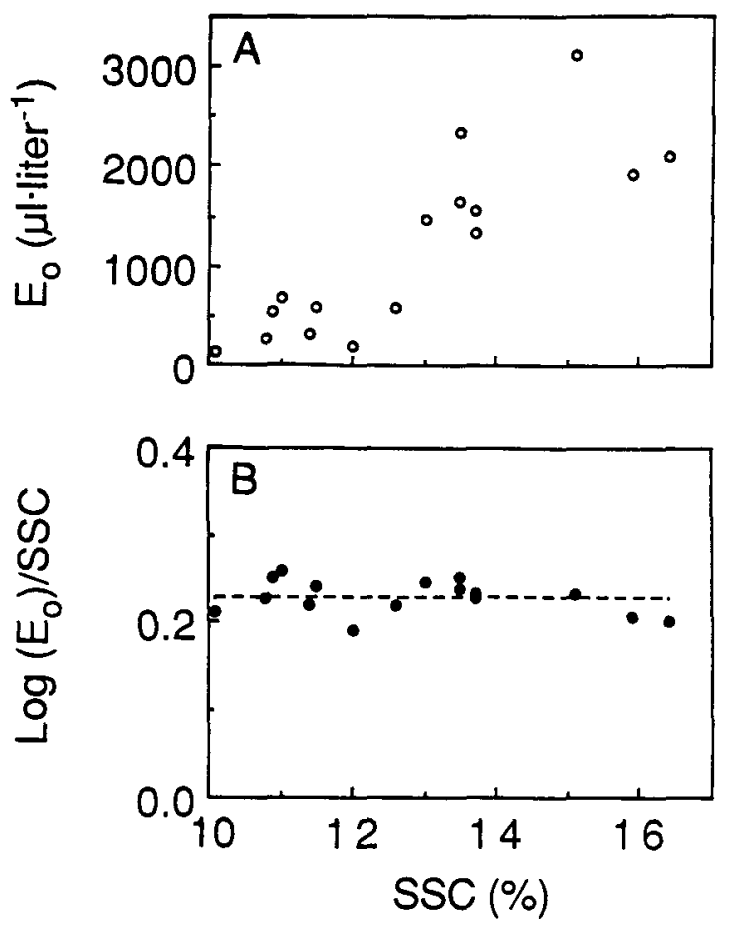

Fig. 6. Relationship between soluble solids content (SSC) and ethanol content causing slight off-flavor $\left(\mathrm{E}_{\mathrm{O}}\right)$ in low- $\mathrm{O}_{2}$-treated 'Granny Smith' and 'Yellow Newtown' apples, '20th Century' pears, and 'Angeleno' plums.

could reasonably predict fruit tolerance to low- $\mathrm{O}_{2}$ atmospheres with a deviation of 1 to 2 days between the predicted and observed tolerance limits. For the practical application of the model to postharvest insect disinfestation, fruit tolerance to low- $\mathrm{O}_{2}$ atmospheres appears to be predictable; with additional information from entomologists, optimum combinations of $\mathrm{O}_{2}$ level and temperature could be selected so that the insects of concern could be killed without detrimental effects on the commodity. 


\section{Literature Cited}

Aharoni, Y., P. Hartsell, J.K. Stewart, and D.K. Young. 1979. Control of western flower thrips on harvested strawberries with acetaldehyde in air, $50 \%$ carbon dioxide or $1 \%$ oxygen. J. Econ. Entomol. 72:819-822.

Anderson, R.E. 1982. Long-term storage of peaches and nectarines intermittently warmed during controlled-atmosphere storage. J. Amer. Soc. Hort. Sci. 107:214-216.

Bramlage, W.J. 1977. Pretreatment of CA 'McIntosh' with high $\mathrm{CO}_{2}$, p. 182-188. In: D.H. Dewey (ed.). Controlled atmospheres for the storage and transport of perishable agricultural commodities. Hort. Rpt. 28, Michigan State Univ., East Lansing.

Chen, P.M., W.M. Mellenthin, S.B. Kelly, and T.J. Facteau. 1981. Effects of low oxygen and temperature on quality retention of 'Bing' cherries during prolonged storage. J. Amer. Soc. Hort. Sci. 106:533535.

Chen, P.M., K.L. Olsen, and M. Meheriuk. 1985. Effect of lowoxygen atmosphere on storage scald and quality preservation of 'Delicious' apples. J. Amer. Soc. Hort. Sci. 110:16-20.

Chen, P.M., D.M. Varga, E.A. Mielke, and S.R. Drake. 1989. Poststorage behavior of apple fruit after low oxygen storage as influenced by temperature during storage and in transit. J. Food Sci. 54:993996.

Claypool, L.L. and F.W. Allen. 1951. The influence of temperature and oxygen level on the respiration and ripening of Wickson plums. Hilgardia 21:129-160.

Couey, H.M. 1960. Effects of temperature and modified atmosphere on the storage life, ripening behavior, and dessert quality of Eldorado plums. Proc. Amer. Soc. Hort. Sci. 75:207-215.

Couey, H.M. 1965. Modified atmosphere storage of Nubiana plums. Proc. Amer. Soc. Hort. Sci. 86:166-168.

Couey, M. and K. Olsen. 1977. Commercial use of prestorage carbon dioxide treatment to retain quality in Golden Delicious apples, $\mathrm{p}$. 165-169. In: D.H. Dewey (ed.). Controlled atmospheres for the storage and transport of perishable agricultural commodities. Hort. Rpt. 28, Michigan State Univ., East Lansing.

Dewey, D.H. and M.L. Bourne. 1982. Low oxygen CA storage of McIntosh apples, p. 101-107. In: D.G. Richardson and M. Meheriuk (eds.). Controlled atmospheres for storage and transport of perishable agricultural commodities. Timber Press, Beaverton, Ore.

Fidler, J.C. and C.J. North. 1971. The effect of periods of anaerobiosis on the storage of apples. J. Hort. Sci. 46:213-221.

Johnson, D.S. and U. Ertan. 1983. Interaction of temperature and oxygen level on the respiration rate and storage quality of Idared apples. J. Hort. Sci. 58:527-533.

Kader, A.A. 1986. Biochemical and physiological basis for effects of controlled and modified atmospheres on fruits and vegetables. Food Technol. 40(5):99-100, 102-104.

Ke, D. and A.A. Kader. 1990. Tolerance of 'Valencia' oranges to controlled atmospheres as determined by physiological responses and quality attributes. J. Amer. Soc. Hort. Sci. 115:779-783.

Ke, D., L. Goldstein, M. O'Mahony, and A.A. Kader. 1991. Effects of short-term exposure to low $\mathrm{O}_{2}$ and high $\mathrm{CO}_{2}$ atmospheres on quality attributes of strawberries. J. Food Sci. 56:50-54.

Ke, D., H. van Gorsel, and A.A. Kader. 1990. Physiological and quality responses of 'Bartlett' pears to reduced- $\mathrm{O}_{2}$ and enhanced$\mathrm{CO}_{2}$ atmospheres and storage temperature. J. Amer. Soc. Hort. Sci. 115:435-439.

Kerbel, E., D. Ke, and A.A. Kader. 1989. Tolerance of 'Fantasia' nectarines to low $\mathrm{O}_{2}$ and high $\mathrm{CO}_{2}$ atmospheres, p. 196-202. In: D. Reid (ed.). Proc. Intl. Inst. Refrigeration Conf. Techn. Innovations Freezing Refrigeration Fruit Veg., Univ. of California, Davis.

Lau, O.L. 1983. Effects of storage procedures and low oxygen and carbon dioxide atmospheres on storage quality of 'Spartan' apples. J. Amer. Soc. Hort. Sci. 108:953-957.

Lidster, P.D., H.J. Lightfoot, and K.B. McRae. 1983. Fruit quality and respiration of 'McIntosh' apples in response to ethylene, very low oxygen and carbon dioxide storage atmospheres. Scientia Hort. 20:71-83.

Lidster, P.D., K.H. Sanford, and K.B. McRae. 1981. Effects of modified atmosphere storage on overwintering populations of the apple rust mite and European red mite eggs. HortScience 16:328-329.

Lidster, P.D., K.H. Sanford, and K.B. McRae. 1984. Effects of temperature and modified atmosphere on survival of overwintering populations of European red mite eggs on stored 'McIntosh' apple. HortScience 19:257-258.

Little, C.R., J.D. Faragher, and H.J. Taylor. 1982. Effects of initial oxygen stress treatments in low oxygen modified atmosphere storage of 'Granny Smith' apples. J. Amer. Soc. Hort. Sci. 107:320-323.

Little, C.R. and I.D. Peggie. 1987. Storage injury of pome fruit caused by stress levels of oxygen, carbon dioxide, temperature, and ethylene. HortScience 22:783-790.

Liu, F.W. and L.J. Ci. 1986. Responses of daminozide-sprayed 'McIntosh' apples to various concentrations of oxygen and ethylene in simulated CA storage. J. Amer. Soc. Hort. Sci. 111:400-403.

Maxie, E.C., B.J. Robinson, and P.B. Catlin. 1958. Effect of various oxygen concentrations on the respiration of Wickson plum fruit and fruit tissues. Proc. Amer. Soc. Hort. Sci. 71:145-156.

Nichols, W.C. and M.E. Patterson. 1987. Ethanol accumulation and poststorage quality of 'Delicious' apples during short-term, low- $\mathrm{O}_{2}$, CA storage. HortScience 22:89-92.

Patterson, M.E. 1982. CA storage of cherries, p. 149-154. In: D.G. Richardson and M. Meheriuk (eds.). Controlled atmospheres for storage and transport of perishable agricultural commodities. Timber Press, Beaverton, Ore.

Patterson, M.E. and W.C. Nichols. 1988. Metabolic response of 'Delicious' apples to carbon dioxide in anoxic and low-oxygen environments. HortScience 23:866-868.

Porritt, S.W. and M.M. Meheriuk. 1977. Effect of $\mathrm{CO}_{2}$ treatment on storage behavior of apples and pears, p. 170-174. In: D.H. Dewey (ed.). Controlled atmospheres for the storage and transport of perishable agricultural commodities. Hort. Rpt. 28, Michigan State Univ., East Lansing.

Richardson, D.G. 1985. CA recommendations for pears (including Asian pears), p. 422-444. In: S.M. Blankenship (ed.). Controlled atmospheres for storage and transport of perishable agricultural commodities. Hort. Rpt. 128, North Carolina State Univ., Raleigh.

Saltveit, M.E. 1982. Procedure for extracting and analyzing internal gas samples from plant tissue by gas chromatography. HortScience 17:878-881.

Sive, A. and D. Resnizky. 1979. Extension of the storage life of 'Red Rosa' plums with controlled atmosphere storage. Bul. Intl. Inst. Refrig. 59:1148.

Smilanick, J.L. and D.C. Fouse. 1989. Quality of nectarines stored in insecticidal low- $\mathrm{O}_{2}$ atmospheres at 5 and 15C. J. Amer. Soc. Hort. Sci. 114:431-436.

Soderstrom, E.L. and D.G. Brandl. 1987. Controlled atmospheres for postharvest control of codling moth on fresh tree fruits. 1986 Res. Rpt., California Tree Fruit Agreement, Sacramento.

Trout, S.A., E.G. Hall, R.N. Robertson, F.M.V. Hackney, and S.M. Sykes. 1942. Studies in the metabolism of apples. 1. Preliminary investigation on internal gas composition and its relation to changes in stored Granny Smith apples. Austral. J. Expt. Biol. Med. Sci. 20:219-223.

Wang, C.Y. and R.E. Anderson. 1982. Progress of controlled atmosphere storage and intermittent warming of peaches and nectarines, p. 221-228. In: D.G. Richardson and M. Meheriuk (eds.). Controlled atmospheres for storage and transport of perishable agricultural commodities. Timber Press, Beaverton, Ore.

Wankier, B.N., D.K, Salunkhe, and W.F. Campbell. 1970. Effects of controlled atmosphere storage on biochemical changes in apricot and peach fruits. J. Amer. Soc. Hort. Sci. 95:604-609.

Zagory, D., D. Ke, and A.A. Kader. 1989. Long term storage of 'Early Gold' and 'Shinko' Asian pears in low oxygen atmospheres p. 353357. In. J.K. Fellman (ed.). Proc. Fifth Intl. Controlled Atmospheres Res. Conf., Wenatchee, Wash. 